\title{
An Assessment of Fathers' Child Abuse Potential in Terms of Their History of Being Maltreated by Their Fathers
}

\author{
Babaların Çocukluk Dönemlerinde Kendi Babaları Tarafından İstismar Edilme \\ Durumlarına Göre Çocuk İstismarı Potansiyellerinin Değerlendirilmesi
}

\section{Utku BEYAZIT * Aynur BÜTÜN AYHAN**}

\begin{abstract}
The aim of this study was to assess the fathers' child abuse potential in terms of their history of being maltreated by their own fathers during childhood. The participants in the study were 171 fathers who were selected by using convenience sampling. An "Individual Information Form", prepared by the authors in order to collect socio-demographic information, was administered to fathers. In addition to this form the, "Child Abuse Potential Inventory", developed by Milner to examine child abuse potential, was administered to fathers. As a result, the child abuse potential of the fathers who had been emotionally abused and neglected by their fathers in childhood were found to be higher than the fathers who were not abused or neglected by their fathers. The findings provide evidence that links the fathers' childhood maltreatment experiences with the future risk of their abusing their own children. The results of the study are discussed in line with the implications on strategies for child maltreatment prevention.
\end{abstract}

Keywords: Father, Child, Child Abuse Potential

Öz: Bu çalışma, babaların çocukluk dönemlerinde kendi babaları tarafından istismar edilme durumlarına göre çocuk istismarı potansiyellerinin incelenmesi amacıyla yapılmıştır. Çalışmanın örneklem grubunu elverişli örnekleme yöntemi ile belirlenen 171 baba oluşturmuştur. Babalara, araştırmacılar tarafindan sosyo-demografik bilgi edinebilmek amacıyla hazırlanan "Kişisel Bilgi Formu" ve Milner tarafindan çocuk istismarı potansiyelini değerlendirmek amacıyla geliştirilen "Çocuk İstismarı Potansiyeli Envanteri” uygulanmıştır. Çalışma sonucunda çocukluk dönemlerinde babaları tarafından duygusal açıdan istismar gören ve ihmal edilen babaların çocuk istismarı potansiyellerinin daha yüksek olduğu tespit edilmiştir. Çalışma sonuçlarının, babaların çocukluk çağı istismar yaşantıları ile kendi çocuklarını istismar etme riskleri arasında ilişki olabileceğine dair ipuçları sunduğu düşünülmektedir. Araştırma sonucunda elde edilen bulgular, çocuk istismarının önlenmesine yönelik stratejiler kapsamında tartışılmıştır.

Anahtar sözcükler: Baba, Çocuk, Çocuk İstismarı Potansiyeli

\section{Introduction}

Child maltreatment, which is defined as the intentional or unintentional negative behavior of the adults who are responsible for taking care of children (World Health Organization 2014). It includes all forms of abuse and neglect, with results in potential or actual harm, and leads to

\footnotetext{
* Asst. Prof., Akdeniz University, Kumluca Faculty of Health Sciences, Child Development Department, Antalya. proz2proz@yahoo.com, https://orcid.org/0000-0002-2596-9091.

** Prof. Dr., Ankara University, Faculty of Health Sciences, Child Development Department, Ankara.

a_butun@yahoo.com, https://orcid.org/0000-0003-3306-9672
} 
consequences that negatively affect the physical and the psychosocial development of the child, in both the short and long term (Eslick, Koloskic \& Talley 2011; Şahin 2014). The World Health Organization (2014) reported that $25-50 \%$ of all children are victims of physical abuse. According to UNICEF, every year, 500 million to 1.5 billion children across the globe are exposed to physical violence and 275 million children witness domestic violence (UNICEF 2014).

An interaction of social, cultural, individual and situational causes increases the risk of child abuse. According to this interactional perspective, as well as the factors related to their own adult parenting practices, parents may also become perpetrators of child abuse as a consequence in childhood years of their experiences with their own abusive parents (Milner, Robertson \& Logers 1990). There are a limited number of studies showing that parents who have a history of maltreatment in childhood are more predisposed to abuse their own children (Milner et al. 1990; Margolin et al. 2003; Rodriguez \& Price 2004). The interaction among the parent's present family and their family of origin is a considerable factor that could trigger abusive parent-child dynamics (Milner et al. 1990). That is, when a person who is exposed to maltreatment in the childhood, then growing up and maltreating her or his own children or having an increased risk of maltreating their children, the intergenerational transmission of child maltreatment may occur (Schelbe \& Geiger 2017).

Traditionally, mothers are regarded to be the primary caregivers of the children and fathers are regarded to be the figures who financially support the family. Despite the fact that the roles of fatherhood have changed and socially gained importance as well as motherhood in today's world (Şahin \& Özbey 2009; Finn \& Henwood 2009), fathers in the family of origin are strong psychological sources for the fathers of the modern day. The fathers' relationship with their own fathers determines the nature of the relationship they establish with their own children and how they form their fatherhood in their current families (Dick 2011; Karaköse \& Karaköse 2012; Shulman \& Sieffge-Krenke 2016). Some fathers may adopt negative attitudes towards their children from being exposed to abuse or neglect by their fathers in their own childhoods (Lee et al. 2008). When the interaction of the father with the child is reduced or damaged for reasons such as the inability to have frequent contact or communication with the child, it may cause various behavioral and emotional problems in the child (Boechler et al. 2003; Şahin \& Özbey 2009). The fathers who were rejected and did not receive approval from their parents, could feel intense anger towards their parents. According to Tuna (2010), a constant high level of anger and insufficient anger management are found to be among the factors increasing the risk of child abuse. Those children who experience emotional closeness and the father' involvement, develop positive self-perceptions and display less aggression (Dubowitz 2006; Kuzucu \& Özdemir 2013). In a study, Horwitz et al. (2001) found that men who had a history of being abused in their childhood had antisocial tendencies as adults, which is a psychopathological risk factor in terms of child abuse potential.

In the literature, the causes of child abuse are examined in line with the contributing role of social context and the individual psychopathologies of both the parents and the children. However, a psychological predisposition to abuse children and the link to the fathers' history of being maltreated in childhood remains unclear and debatable. There is a need for a current and in-depth focus on the intergenerational characteristics of child maltreatment. In the literature, the subjects of intergenerational transmission of abuse and child abuse potential are discussed frequently, although independently. No studies have examined the combination of these two relevant subjects. On the other hand, most studies about parenting and child abuse focus on mothers, as mothers are considered to be the children's primary caregivers in Turkish culture. The role of fathers certainly deserves more in-depth investigation. Within this context, in this study analysis, the aim was to assess the intergenerational transmission of abuse by focusing on 
the assumption that a childhood history of maltreatment may lead to child abuse potential in fathers.

\section{Method \\ Participants}

The participants of this study were 171 fathers who were selected employing a convenience sampling method. The fathers were drawn from the general population of north Cyprus and were recruited by email, through face-to-face contact or social media. The inclusion criteria were having children under 18 years old, volunteerism and availability. The fathers participating in the study were also invited to contact other fathers they knew. In the study, $7.6 \%(n=13)$ of the fathers were aged 29 or under 29, 31.6\% $(n=54)$ were between 30 and 39, 28.7\% $(n=49)$ were between 40 and 49 and 32.2\% $(n=55)$ were between 50 and 59 .

\section{Instruments}

In the study, an "Individual Information Form" was prepared by the authors for the purpose of gathering data about the participants' age. In the form, the fathers were also asked whether they had been exposed to emotional and physical neglect or abuse by their fathers in childhood. Sexual abuse history was not assessed in the study due to ethical and confidentiality concerns. In addition to this form, the participants also completed the Child Abuse Potential Inventory.

Child Abuse Potential Inventory (CAPI). CAPI was developed by Joel Milner in order to assess the abuse potential of adults towards children. Child abuse potential is a specific construct of self-reported parental characteristics, which refers to unhappiness, stress, rigidity, poor egostrength, intrapersonal as well as interpersonal difficulties, unrealistic expectations about children's behavior and misperceptions of appropriate childhood behavior (Milner \& Ayoub 1980).

The studies for the inventory initially started in 1983 and many other studies have been conducted in order to determine its validity and reliability to the present. Since the onset of the development of the inventory, over 100 articles have been published regarding the psychometric properties of this instrument. The inventory has been continuously revised and developed over the years and a manual for the tool was published in 2006. CAPI has been recently used in many countries for objectives such as screening and monitoring of those parents who are at risk of committing child abuse. Hence, CAPI is used to assess child abuse potential in this study, despite the fact that it is a relatively old instrument. The lack of any Turkish measures to assess the subject of concern is another reason why this instrument was chosen for use in this study.

CAPI consists of 160 items and includes a subscale of child physical abuse and six other subscales, which are unhappiness, rigidity, distress, family problems, problems with child and self, and problems with others. The items can be answered either as "I agree" or "I disagree". The calculation of the scores is conducted according to a scoring chart in the annex of the inventory. According to this chart, each question has a different weight score. A total score is computed by totaling all of the item scores. The highest possible score is 486 . While individuals receiving 166 or more are identified as "risky groups" with high abuse potential, the individuals below that score are defined as "the normal group" (Milner 2003). The validity study of CAPI in Turkey was conducted by Kutsal (2004), and the Cronbach's alpha coefficient was calculated as 0.94. In a validation study of CAPI in a Turkish sample, Kutsal et al. (2011) calculated the cut off score as 200.5. For this study, the cut off score was taken as 200.5 and Cronbach's alpha coefficient of CAPI was found to be 0.921 .

\section{Data Collection and Data Analysis}

Initially, approval was obtained from Near East University Scientific Research Assessment Ethics Board for this study. Written consents were also obtained from the authors of the scales 
used in the study. The fathers were given information about the content of the study and they subsequently gave their consent to participate. It was also explained to the fathers that their responses would be confidential.

In order analyze the data obtained from the study, SPSS 21 was used. In the data analysis, the normality test was conducted to examine whether the prioritized parametrical test conditions were provided. The conformity of the data to normality distribution was assessed with the Shapiro-Wilk test. In this study, the Shapiro-Wilk test was preferred since it is stronger than other normality tests and provides sensitive results from both small and large samples. Accord to the results, the data collected was found to be non-parametric. Therefore, the Mann-Whitney $\mathrm{U}$ was employed in terms of the comparison analysis.

\section{Results}

Table 1. The Arithmetic Mean and the Standard Deviations of the scores of CAPI

\begin{tabular}{lccccc}
\hline CAPI Scores & $\mathrm{n}$ & Minimum & Maximum & Mean & St. Dev. \\
\hline Normal Group & 136 & 10 & 193 & 99.11 & 44.30 \\
Risky Group & 35 & 201 & 325 & 259.06 & 38.39 \\
Total & 171 & 10 & 325 & 131.84 & 77.73 \\
\hline
\end{tabular}

Table 1 indicates that the fathers had a Child Abuse Potential Inventory score average of 131.84 \pm 77.73 . It was found that 35 fathers were in the risk group, in terms of child abuse potential. The average score of the fathers identified in the risk group was $259.06 \pm 38.39$, while their score range was 201-325. The average score of 136 fathers identified in the normal group in terms of child abuse potential was 99.11 \pm 44.30 , while their score range was 10-193.

Table 2. The Mann-Whitney U Test Results From The Comparison of The CAPI Scores According To The Fathers' Childhood History of Physical and Emotional Abuse and Neglect by Their Fathers

\begin{tabular}{|c|c|c|c|c|c|c|}
\hline Type of Maltreatment & $n$ & Mean Rank & Sum of Ranks & $\mathrm{U}$ & $\mathrm{p}$ & Effect Size \\
\hline $\begin{array}{l}\text { Physical Abuse } \\
\text { Yes } \\
\text { No }\end{array}$ & $\begin{array}{c}59 \\
112\end{array}$ & $\begin{array}{l}92.79 \\
82.42\end{array}$ & $\begin{array}{l}5474.50 \\
9231.50\end{array}$ & 2903.500 & 0.193 & 0.2 \\
\hline $\begin{array}{l}\text { Emotional Abuse } \\
\text { Yes } \\
\text { No }\end{array}$ & $\begin{array}{c}21 \\
149\end{array}$ & $\begin{array}{c}115.98 \\
81.20\end{array}$ & $\begin{array}{c}2435.50 \\
12099.50\end{array}$ & 924.500 & $0.002 *$ & 0.478 \\
\hline $\begin{array}{l}\text { Neglect } \\
\text { Yes } \\
\text { No }\end{array}$ & $\begin{array}{c}116 \\
54\end{array}$ & $\begin{array}{c}75.28 \\
107.45\end{array}$ & $\begin{array}{l}8732.50 \\
5802.50\end{array}$ & 1946.500 & $0.00^{* *}$ & 0.639 \\
\hline
\end{tabular}

The results on Table 2 related to the comparison of CAPI scores according to the fathers' childhood history of emotional and physical abuse and neglect by their fathers, by employing the Mann Whitney-U test, shows that there is no significant difference between the mean ranks of the physically abused and the non-abused groups $(u=2903.500, p>.05)$. As with the emotional abuse, the fathers' child abuse potential who were emotionally abused by their fathers was found to be significantly higher than the fathers who reported that they were not emotionally abused by their own fathers $(u=924.500, p<.05)$. As with neglect, the fathers' child abuse potential who were neglected by their fathers was significantly higher than the fathers who were not neglected $(u=1946.500, p<.01)$. An assessment of the effect size about the analysis of physical abuse (0.2) reveals a low effect level, whereas the effect size related to emotional abuse (0.478) and neglect (0.639) reveals a high level of effect in terms of the criteria 
of Cohen's d (1988). According to these criteria, an effect size of 0.1 and above indicates a low effect level, whereas 0.3 and above indicates a moderate level and 0.5 and above indicates a high effect level.

\section{Discussion}

The present study examined fathers' child abuse potential in terms of their history of being maltreated by their own fathers in childhood. According to these findings, the fathers' child abuse potential, of those fathers who were emotionally abused by their fathers was higher than those fathers who were not emotionally abused by their own fathers. The child abuse potential of those fathers who were neglected by their fathers was also significantly higher than the fathers who reported that they were not neglected. However, the fathers' child abuse potential did not differ according to whether they were physically abused by their fathers or not.

These findings provide evidence that links the childhood maltreatment experiences of fathers and the risk of their abusing their own children and they are consistent with a number of findings in the literature. Merril (1996) found that fathers' experiences of parent-child physical violence contributed to their risk of physical child abuse. They also reported that fathers who recalled parental violence from their childhood had higher physical child abuse potential. In another study conducted by Margolin et al. (2003), the links between domestic violence, child abuse potential and aggression in the family of origin were examined in a sample of 181 families. In the study, it was found that those fathers who had been exposed to forms of aggression in their family of origin had a higher potential of abusing their children as they are found to be engaged in stressful parenting practices more than the mothers. A limited number of other studies assessed the link between both mothers' and fathers' childhood history of maltreatment and their potential of abusing their children. In a study conducted by Milner et al. (1990) which contained 375 participants, it was found that that there is a significant association between the history of abuse in childhood and child abuse potential in adulthood. Rodriguez and Price (2004) also found that a history of abusive discipline practices was shown to be a significant predictor of future child abuse potential in a sample 140 college students. In a study of Can and Beyazit (2018) the traumatic effects of childhood abuse experiences were found to be a predictor of child abuse potential in the adulthood.

Although, a history of maltreatment may be linked to an increased potential for child abuse in adults, it should also be stated that not all parents who have a history of maltreatment in childhood, abuse their children in adulthood. In a study conducted by Ertem et al. (2000) which reviewed studies published between 1965 and 2000 in English that provided data about physical abuse over two generations, only ten studies were identified that met these criteria. In another study on a sample of 920 parents, Romero-Martinez et al. (2014) also indicated that fathers who had a history of physical abuse had lower potential of perpetrating physical abuse against their children than mothers. Similarly, in a 30-year follow-up study which interviewed fathers and mothers who had histories of childhood maltreatment, Widow et al. (2015) could not justify the intergenerational transmission of physical abuse, whereas they found strong evidence for neglect. In their study, they pointed out that efforts of public education to call attention to and avoid physical abuse may have an effect on attitudes of the society toward abuse, or may have a negative effect on the willingness to report physical abuse.

Despite the limited data related to the intergenerational characteristics of child abuse, the findings of the present study suggest that a history of maltreatment may increase the potential of child abuse in adult men. Blizard (2006) emphasized that the parenting practice itself can become traumatizing to the parent if they were abused in their childhood. Each time the child approaches the parents to seek affection, attention or protection, the traumatic effect is triggered 
in the parent. The parent's negative reaction may cause the child to become frustrated or aggressive and can result in avoidance of the abusing parent. This in turn may trigger feelings of anger and frustration in the parent, rendering it impossible for the parent to respond to the child in an appropriate way and may precipitate abuse of the child (Geiger \& Schelbe 2014). Ney (1988) suggested that a child's cry may evoke the childhood memories of pain from the parents. As anxiety and anger aggravates the crying, the parent may become tired, desperate and neglectful. The outbreak of maltreatment aggravates the guilty feelings of the parent, which may increase the likelihood for further maltreatment. Sometimes, the parents could be trying to compensate for the feelings of worthlessness, loneliness, isolation and mistrust triggered by memories of abuse, by maltreating their own child (Polat 2007).

The exposure to abuse and neglect by the father during childhood may be affecting negatively the fatherhood perception of children. In a study of Zeren et al. (2012) involving 150 students between the ages of 17 and 26, it was found that the individuals exposed to negative emotional experiences in their childhood still had difficulties and experienced mistrust in their interpersonal relationships in adulthood. Zeren et al. suggested that children exposed to such traumatic experiences might develop negative perceptions regarding their parents and could experience problems in their relationships with their own children. Today, the belief that physical punishment is necessary for the training of the child and therefore, physical violence can be beneficial, still exists in Turkish culture. An individual who develops while being exposed to violence by the father may have negative opinions and attitudes towards the role of fatherhood, resulting in an increased risk of abusing their own children. On the other hand, it can be argued that being maltreated by their own fathers may bring psychological stressors such as anger and frustration and fathers who were maltreated by their own fathers may direct these feelings towards their own children. Thus, fathers' experiences with their own fathers may become a risk factor for increasing their potential for child abuse.

\section{Conclusion}

The findings of this study suggest that child maltreatment may have transgenerational characteristics, as those fathers who are exposed to abuse by their fathers in their own childhood may become predisposed to abuse their own children. However, it should be noted that the cycle of abuse is not straightforward and may involve complicated links with many other mediating factors. However, the findings of the study are potentially informative, as, to the best of the researchers' knowledge, this is the first ever research to examine this subject in a Turkish population. The findings may provide a deeper comprehension about the cycle of child maltreatment and could have implications for professionals working with families. The parents who are at risk of maltreating their children should be encouraged and helped to gain awareness about the negative reflections of the problems they experienced in childhood and should be provided long-term individual psychotherapy, family therapy and early intervention services to find solutions to problems experienced in childhood. It must be ensured that the parents adopt positive child raising attitudes that do not include violence in the education of children. The parents who are identified to be at risk of child maltreatment and have inadequate parenting skills may benefit from effective parenting skills training. They can also be trained in individual skills for becoming more consistent and communicative, reducing the negative exchanges between themselves and their children.

A number of the limitations to this study should also be pointed out. Firstly, the study relied upon the retrospective self-reporting of the participants. The participants may have recalled and reported the incidences that occurred in their childhood both subjectively and inaccurately. The findings of the study rely upon a limited sample size. In terms of generalizability, the results 
need replication in larger samples. Although the study reveals a link between a history of maltreatment in childhood and child abuse potential in adulthood, not all fathers who were maltreated in their childhood, in adulthood maltreat their own children, as is discussed above. Possible mediator factors such as socio-demographic variables, the effect of social support, attachment and individual psychopathologies should be examined. In future studies, a comparison of paternal versus maternal childhood maltreatment may provide more insight about the intergenerational transmission of maltreatment in fathers. The use of adopted measurement instruments regarding fatherhood which have culturally specific characteristics is another limitation of the study. However, it should also be pointed out that there are no local instruments to assess the concept of child abuse potential. Along with the quantitative methods, a qualitative study in which the participants discuss their childhood experiences with their fathers and how these experiences affect their parenting practices can be conducted in future studies.

\section{REFERENCES}

Blizard R. P. (2006). "Prevention of Intergenerational Transmission of Child Abuse: A National Priority". Journal of Trauma \& Dissociation 7/3 (2006) 1-6. Doi: 10.1300/J229v07n03_01.

Boechler V., Harrison M. J. \& Magill-Evans J. (2003). "Father-Child Teaching Interactions: The Relationship to Father Involvement in Caregiving”. Journal of Pediatric Nursing 18/1 (2003) 46-51. Doi: 10.1053/jpdn.2003.7.

Can G. \& Beyazıt U. (2018). "Çocuk İstismarı Potansiyelini Yordayan Faktörlerin İncelenmesi”. MJH VIII/1 (2018) 87-99. Doi: 10.13114/MJH.2018.385.

Cohen J. (1988). Statistical Power Analysis for the Behavioral Sciences. New York 1988.

Dick G. L. (2011). "The Changing Role of Fatherhood: The Father as a Provider of Self Object Functions”. Psychoanalytic Social Work 182 (2011) 107-125. Doi: 10.1080/15228878.2011.

Dubowitz H. (2006). "Where's Dad? A Need to Understand Father's Role in Child Maltreatment”. Child Abuse \& Neglect 30 (2006) 461-465. Doi: 10.1016/j.chiabu.2006. 04.002.

Ertem O., Leventhal J. M. \& Dobbs S. (2000). "Intergenerational Continuity of Child Physical Abuse: How Good Is The Evidence?” Lancet (2000) 356 814-19. Doi: 10.1016/S0140-6736(00)02656-8.

Eslick G. D., Koloskic N. A. \& Talley N. J. (2011). "Sexual, Physical, Verbal/Emotional Abuse and Unexplained Chest Pain”. Child Abuse \& Neglect 35 (2011) 601-605. Doi: 10.101 6/j.chiabu.2011.04.007.

Finn M. \& Henwood K. (2009). “Exploring Masculinities Within Men’s Identificatory Imaginings of First-Time Fatherhood”. British Journal of Social Psychology 48 (2009) 547-562.

Geiger J. M. \& Schelbe L. A. (2014). "Stopping the Cycle of Child Abuse and Neglect: A Call to Action to Focus on Pregnant and Parenting Youth in and Aging Out of the Foster Care System". Journal of Public Child Welfare 8 (2014) 25-50. Doi: 10.1080/15548732.2013.824398.

Horwitz A. V., Widom C. S., McLaughlin J., \& Raskin H. (2001). "The impact of childhood abuse and neglect on adult mental health: a prospective study". Journal of Health and Social Behavior 42/2 (2001) 184-201.

Karaköse Ş. \& Karaköse R. (2012). Çocuk Eğitiminde Babanın Etkisi. İstanbul 2012.

Kutsal E. (2004). The Socio-Demographic Characteristics of Physical Child Abuse and the Turkish Validity Study of Milner Child Abuse Inventory. Unpublished Master Thesis. Gazi University, Faculty of Medicine, Ankara 2004.

Kutsal E., Paslı F., Işıklı Ş., Şahin F., Yılmaz G. \& Beyazova U. (2011). "Preliminary Validation of the Child Abuse Potential Inventory in Turkey”. Journal of Interpersonal Violence 26 (2011) 2856-2865. Doi:10.1177/0886260510390952.

Kuzucu Y. \& Özdemir, Y. (2013). "Ergen Ruh Sağlığının Anne ve Baba Katılımı Açısından Yordanması". Eğitim ve Bilim 38/168 (2013) 96-112.

Lee J., Guterman N. B. \& Lee Y. (2008). "Risk Factors for Paternal Physical Child Abuse”. Child Abuse \& Neglect 32 (2008) 846-858. Doi:10.1016/j.chiabu.2007.11.006.

Margolin G., Gordis E. B., Medina A. M. \& Oliver P. H. (2003). “The Co-Occurrence of Husband-to- 
Wife Aggression, Family-of-Origin Aggression, and Child Abuse Potential in a Community Sample. Implications for Parenting”. Journal of Interpersonal Violence 18/4 (2003) 413-440. Doi: 10.1177/0886260502250835.

Merril L. L. (1996). “Childhood Parenting Experiences, Intimate Partner Conflict Resolution, and Adult Risk for Child Physical Abuse”. Child Abuse \& Neglect 20/11 (1996) 1049-1065.

Milner J. S. (2003). “Social Information Processing in High-Risk and Physically Abusive Parents”. Child Abuse \& Neglect 27 (2003) 7-20.

Milner J. S. \& Ayoub C. (1980). "Evaluation of 'At Risk' Parents Using the Child Abuse Potential Inventory”. Journal of Clinical Psychology 36/4 (1980) 945-948.

Milner J. S., Robertson K. R. \& Rogers D. L. (1990). “Childhood History of Abuse and Adult Child Abuse Potential”. Journal of Family Violence 5/1 (1990) 15-43.

Ney P. N. (1988). “Transgenerational Child Abuse”. Child Psychiatry and Human Development 18/3 (1988) 151-68.

Polat O. (2007). Child Abuse Definitions [In Turkish]. Ankara 2007.

Rodriguez C. M. \& Price B. L. (2004). “Attributions And Discipline History As Predictors of Child Abuse Potential and Future Discipline Practices”. Child Abuse \& Neglect 28 (2004) 845-861.

Romero-Martinez A., Figueiredo B. \& Moya-Albiol A. (2014). "Childhood History of Abuse and Child Abuse Potential: The Role of Parent's Gender and Timing of Childhood Abuse”. Child Abuse \& Neglect 38/3 (2014) 510-516. Doi: https://doi.org/10.1016/j.chiabu.2013.09.010.

Schelbe L. \& Geiger J. M. (2017). What is Intergenerational Transmission of Child Maltreatment?. Intergenerational Transmission of Child Maltreatment. USA 2014.

Shulman S. \& Seiffge-Krenke I. (2016). Fathers and Adolescents Developmental and Clinical Perspectives. USA 2016.

Şahin F. (2014). Fiziksel İstismar. Çocuk İstismarına ve İhmaline Yaklaşım. Temel Bilgiler. Ankara 2014.

Şahin F. T. \& Özbey S. (2009). "Okulöncesi Eğitim Programlarında Uygulanan Aile Katılım Çalışmalarında Baba Katılımının Yeri ve Önemi”. Aile ve Toplum 5/17 (2009) 30-40.

Tuna S. (2010). Child Abuse in Family: An Investigation of Mothers About Some Risk Factors. Unpublished Master Thesis, University of Istanbul, Institute of Social Sciences, Istanbul 2010.

UNICEF (2014). The State of the World's Children 2014 in Numbers. New York 2014.

Widow C. S., Czaja S. J. \& DuMont K. A. (2015). "Intergenerational Transmission of Child Abuse And Neglect: Real Or Detection Bias?”. Science 347/6229 (2015) 1480-1485. Doi: 10.1126/science.1259917.

World Health Organization (2014). “Child Maltreatment (“Child Abuse”)”. Source: http://search.who.int/ search?q=child+abuse\&ie=utf8\&site=who\&client=_en_r\&proxystylesheet=_en_r\&output=xml_no_d td\&oe=utf8\&getfields=doctyp.

Zeren C., Yengil E., Celikel A., Arik A. \& Arslan M. (2012). "Frequency of Childhood Abuse in University Students”. Dicle Medical Journal 39/4 (2012) 536-541. Doi: 10.5798/d iclemedj.0921.2012.04.0196. 